\title{
A Comparison of Body Composition, Residual Biological Function and Dialytic Treatment of 20 Males and 19 Females Undergoing Chronic Peritoneal Dialysis
}

\author{
Giancarlo Ruggieri
}

\begin{abstract}
In this study, 34 variables were compared among 20 males and 19 females undergoing chronic peritoneal dialysis based on four approaches of elaboration. The variables were selected from among a large number of variables of a database, that were available for both males and females. The first approach compared the data between males and females. The second approach performed a correlation between two series of variables available in males and between two series of variables available in females. 64 variables showed 80 positive correlations, and consistent results are shown in four tables; only the statistically significant results are shown. The third approach compared the body water content, calculated as total body water according to the formula by Watson, intracellular water, and extracellular water between males and females. The different forms of body water were normalized by height, weight and body mass index (BMI). Normalization affected the outcomes of values of intracellular and extracellular body water differently. The relevance of these different modifications was shown to depend on the variance of the indexing variables. Total body water, intracellular water and extracellular water were significantly different between males and females, with higher values for males. The only exception was the extracellular water/intracellular water ratio, which was higher for females, showing that females most likely have a larger amount of body water despite their lower body size.
\end{abstract}

Index Terms - males females body composition differences

\section{INTRODUCTION}

\section{Premise}

This study evaluated a series of 34 variables concerning the physical condition, the degrees of biological function, and the dialytic treatment of 20 males and 19 females undergoing chronic peritoneal dialysis. The variables were selected from among many variables based on the availability of the variables in both males and females, as follows: age, height, weight, body mass index (BMI), Cockroft, Cockroft week, urine volume/min, urine volume/100, normalized renal clearance, normalized renal clearance liters per week, dialyzed/min, dialyzed/100, normalized dialysis clearance, normalized dialysis clearance liters week, creatinine dialysis clearance, dialysis clearance liters per week, normalized total clearance week, total creatinine per week, total clearance week, total excreted creatinine per day, ideal excreted creatinine per weight, ideal excreted creatinine per height, excreted creatinine/min according to Cockroft volume/min, normal creatinine clearance according to age, delta $\%$, ideal creatinine according height corrected by age, ideal creatinine according to weight corrected by age, delta of creatinine by Cockroft minus ideal creatinine corrected per height and age, positive delta creatinine by Cockroft minus ideal creatinine per age, excreted creatinine/average, dialysis volume/100, supplementary clearance, supplementary creatinine clearance plus total creatinine clearance, supplementary creatinine clearance $/ \mathrm{kg}$, delta/BMI, and total excreted creatinine/BMI. The variable "delta \%" represents the percentage difference between the selected variable "normal creatinine clearance according to age" and the value of the standard GFR (glomerular filtration rate) not indexed on BSA (body surface area), which was assumed to be normal at $120 \mathrm{ml} / \mathrm{min}$ for males and $110 \mathrm{ml} / \mathrm{min}$ for females in the adult subjects up to forty years of age. GFR successively declines with aging according to increasing rates on the base of a scale diversely evaluated with time by nephrologists. The calculation of delta $\%$ is based on the formula " [(normal creatinine clearance according to age)*100]/110 or 120 , using 120 or 110 according to gender.

\section{METHOD}

The data were analyzed based on four different approaches. 1) Statistical comparison of the male data versus the female data. 2) Evaluation of possible correlations between the variables performed using the statistical software MINITAB 18 (MINITAB, State College, PE, USA) and Pearson correlations, which indicate the degree of the correlation from 0 to and 100 and the probability of significance ( $p)$; significance was considered for $p$ values less than 0.05. 3) Comparison of total body water, extracellular water and intracellular water between males and females. 4) Comparison of the values of intracellular water and extracellular water normalized to height, weight, and BMI.

\section{RESULTS}

Tables I, Table II, and Table III show the statistical comparisons of each variable for males versus females. The results are reported in the following series of tables. 
Table I - Comparison of each variable for males versus females

\begin{tabular}{|l|c|c|}
\hline \multicolumn{1}{|c|}{ Variable } & T value & $\mathrm{p}$ \\
\hline Age & -29.39 & 0.000 \\
\hline Height & 31.27 & 0.000 \\
\hline Weight & 18.24 & 0.000 \\
\hline BMI & 16.09 & 0.000 \\
\hline Cockroft & -13.27 & 0.000 \\
\hline Cockroft week & 19.23 & 0.000 \\
\hline Volume urine/min & -6.97 & 0.000 \\
\hline Volume urine/100 & 8.14 & 0.000 \\
\hline Normalized renal clearance & 2.51 & 0.017 \\
\hline Normalized renal clearance liters week & 2.51 & 0.017 \\
\hline Renal creatinine clearance & 2.56 & 0.015 \\
\hline Renal creatinine clearance liters week & 2.56 & 0.015 \\
\hline Dialyzed/min & 2.1 & 0.043 \\
\hline
\end{tabular}

Table II - Comparison of each variable for males versus females

\begin{tabular}{|l|c|c|}
\hline \multicolumn{1}{|c|}{ Variable } & T value & $\mathrm{p}$ \\
\hline Dialyzed/100 & 2.1 & 0.043 \\
\hline Normalized dialysis clearance & 1.46 & 0.153 \\
\hline Normalized dialysis clearance liters week & 1.46 & 0.153 \\
\hline Creatinine clearance by dialysis & 0.28 & 0.781 \\
\hline Dialysis clearance liters week & 0.28 & 0.781 \\
\hline Normalized total clearance week & 3.87 & 0.000 \\
\hline Total clearance week & 2.95 & 0.006 \\
\hline Total creatinine clearance week & 2.95 & 0.006 \\
\hline Total clearance week & 10 & 0.000 \\
\hline & & \\
Total excreted creatinine dialysis & 0.8 & 0.432 \\
\hline Total excreted creatinine/day & 11.36 & 0.000 \\
\hline Ideal excreted creatinine per weight & 7.68 & 0.000 \\
\hline Ideal excreted creatinine per height & 13.5 & 0.000 \\
\hline
\end{tabular}

\begin{tabular}{|l|c|c|}
\hline \multicolumn{2}{|c|}{ Table III - Comparison of each variable for males versus females } & \multicolumn{2}{l|}{ T value } & P \\
\hline \multicolumn{1}{|c|}{ Variable } & 4.94 & 0.000 \\
\hline Excreted creatinine/min according to Cockroft volume/min & -13.92 & 0.000 \\
\hline Normal CtCl according to age & -23.35 & 0.000 \\
\hline Delta \% & 23.09 & 0.000 \\
\hline Ideal creatinine according to height corrected by age & 10.07 & 0.000 \\
\hline Ideal creatinine according to weight corrected by age & & \\
\hline
\end{tabular}


World Journal of Research and Review (WJRR) ISSN:2455-3956, Volume-7, Issue-1, July 2018 Pages 28-35

\begin{tabular}{|l|c|c|} 
Delta of creatinine by Cockroft minus ideal creatinine corrected by height and age & -12.98 & 0.0000 \\
\hline Positive delta creatinine by Cockroft - ideal creatinine per age & 7.14 & 0.000 \\
\hline Excreted creatinine/average dialysis volume/100 & -20.76 & 0.000 \\
\hline Supplementary clearance & 1.79 & 0.087 \\
\hline Supplementary creatinine clearance + total creatinine clearance & 14.48 & 0.000 \\
\hline Supplementary creatinine clearance/kg & -14.22 & 0.000 \\
\hline Delta/BMI & 0.55 & 0.19 \\
\hline Total excreted creatinine/BMI & 9.66 & 0.000 \\
\hline
\end{tabular}

It can be noted that 1) a non-significant difference was found for seven of the 39 variables (17.95\%); 2) all significant differences (32 out of 39) concerned a prevalence of males versus females (82.05\%); and 3) the non-significant comparisons included normalized dialysis clearance and dialysis amount in liters per week, non-normalized creatinine clearance by dialysis, total excreted creatinine by dialysis, supplementary clearance and delta/BMI. Therefore, the clearances attained by dialysis and the total mass of creatinine excreted by dialysis were very similar in males and females : the clearances attained by dialysis had the same efficacy in both genders. The correlations of the variables, evaluated according to the Pearson method, are reported in the following tables.

\begin{tabular}{|c|c|c|c|c|}
\hline basal variables & correlated variables & $\begin{array}{c}\text { Pearson } \\
\text { correlation }\end{array}$ & $p$ & p scores \\
\hline Age & Ideal creatinine according to weight & -0.516 & 0.02 & 3 \\
\hline Cockroft (Cockr.) & Renal Clearance of creatinine/min & 0.619 & 0.004 & 5 \\
\hline Cockroft (Cockr.) & Excreted creatinine/min according to Cockr. volume/min & 0,45 & 0.047 & 3 \\
\hline Renal Ctreatinine Clearance/min & Total excreted creatinine/day & 0.538 & 0.014 & 3 \\
\hline Urine volume /min & Total excreted creatinine by urine & 0.82 & 0.000 & 7 \\
\hline Urine volume $/ 100$ & Total excreted creatinine/day & 0.491 & 0,028 & 3 \\
\hline weight & Ideal creatinine according to weight & 0.754 & 0.000 & 7 \\
\hline Normalized Total Clearance week & Total excreted creatinine/day & 0,587 & 0.006 & 5 \\
\hline Total Creatinine Clearance week & Total excreted creatinine/day & 0.628 & 0,003 & 5 \\
\hline Urine volume $/ 100$ & Dialysis Creatinine Clearance $(\mathrm{CtCl})$ & -0.608 & 0,004 & 5 \\
\hline Urine volume $/ 100$ & Total Clearance week & 0.549 & 0.012 & 3 \\
\hline Urine volume $/ 100$ & Supplementary $\mathrm{CtCl}+$ total $\mathrm{CtCl}$ & 0,528 & 0.017 & 3 \\
\hline Normalized Renal Clearance week liters & Total excreted Creatinine/BMI & 0.47 & 0.037 & 3 \\
\hline Cockroft (Cockr.) & Total Creatinine Clearance week & 0,522 & 0,018 & 3 \\
\hline Normalized Renal Clearance week liters & Total excreted creatinine/day & $0, .47$ & 0.012 & 3 \\
\hline Dialiyzed/100 & Normalized dialysis dialysis clearance liters week & 0.508 & 0.022 & 3 \\
\hline Normalized total clearance week & Total excreted creatinine by urine & 0.486 & 0.03 & 3 \\
\hline Total excreted creatinine by urine & Total excreted creatinine/day & 0.728 & 0,000 & 7 \\
\hline Age & Ideal creatinine according to weight corrected by age & $-0,516$ & 0.02 & 3 \\
\hline \multirow[t]{4}{*}{ Urine volume/100 } & Total excreted creatinine by urine & 0,82 & 0.000 & 7 \\
\hline & mean & 0.42 & 0.015 & 4.2 \\
\hline & SD & 0.413 & 0.0134 & 1.64 \\
\hline & Coefficient .of Variation & 0.983 & 0.893 & 0.39 \\
\hline
\end{tabular}


A Comparison of Body Composition, Residual Biological Function and Dialytic Treatment of 20 Males and 19 Females Undergoing Chronic Peritoneal Dialysis

\begin{tabular}{|c|c|c|c|c|}
\hline basal variables & correlated variables & $\begin{array}{c}\text { Pearson } \\
\text { correlation } \\
\end{array}$ & $p$ & $\begin{array}{c}p \\
\text { scores }\end{array}$ \\
\hline Supplementary clearance & Normalized total clearance week & -0.459 & 0.042 & 3 \\
\hline Supplementary clearance & Supplementary CtCl/kg & 0.952 & 0.000 & 7 \\
\hline Delta \% & Ideal creatinine according to weight corrected by age & 0.883 & 0,000 & 7 \\
\hline Renal Clearance of creatinine/min & Total Clearance week/min & 0,926 & 0.000 & 7 \\
\hline Urine volume/100 & Renal Clearance of creatinine/min & 0.716 & 0.000 & 7 \\
\hline Urine volume/100 & Total Clearance week/min & 0.82 & 0.000 & 7 \\
\hline Total excreted creatinine/day & Vol U/100 & 0.628 & 0.003 & 5 \\
\hline Total Clearance week/min & Renal Clearance of creatinine/min & 0.926 & 0.000 & 7 \\
\hline Dialysis Creatinine Clearance $(\mathrm{CtCl})$ & Normalized renal clearance of creatinine/min & -0.523 & 0.018 & 3 \\
\hline Total excreted creatinine by dialysis & Vol U/100 & -0.622 & 0.003 & 5 \\
\hline Total excreted creatinine by dialysis & Normalized dialysis clearance & 0.789 & 0.000 & 7 \\
\hline Total excreted creatinine by dialysis & Supplementary $\mathrm{CtCl}+$ total $\mathrm{CtCl}$ & -0.503 & 0.024 & 3 \\
\hline Total excreted creatinine by dialysis & Supplementary CtCl/kg & -0.527 & 0.017 & 3 \\
\hline Supplementary clearance & Positive delta of creatinine by Cockr.- ideal creatinine & 0.957 & 0.000 & 7 \\
\hline Delta/ BMI & Total excreted creatinine/BMI & -0.478 & 0.033 & 3 \\
\hline Delta/ BMI & Ideal excreted creatinine according to weight & 0.793 & 0.000 & 7 \\
\hline Total clearance week/min & Cockroft week & 0.793 & 0.000 & 7 \\
\hline Total clearance week/min & Renal creatinine clearance liters week & 0.926 & 0,000 & 7 \\
\hline Total clearance week/min & Urine volume/100 & 0.549 & 0.012 & 3 \\
\hline \multirow[t]{4}{*}{ Total clearance week/min } & Total excreted creatinine/day & 0.628 & 0.003 & 5 \\
\hline & mean & 0.409 & 0.008 & 5.5 \\
\hline & $\mathrm{SD}$ & 0.633 & 0.013 & 1.82 \\
\hline & Coefficient $f$. of Variation. & 1.55 & 1.625 & 0.331 \\
\hline
\end{tabular}


World Journal of Research and Review (WJRR) ISSN:2455-3956, Volume-7, Issue-1, July 2018 Pages 28-35

Table VI - Females 1 - Correlations of variables according to Pearson correlation

\begin{tabular}{|c|c|c|c|c|}
\hline basal variables & correlated variables & $\begin{array}{c}\text { Pearson } \\
\text { correlation }\end{array}$ & $p$ & $\begin{array}{c}p \\
\text { scores } \\
\end{array}$ \\
\hline age & Ideal creatinine according to weight & $-0 ., 57$ & 0.009 & 5 \\
\hline age & Ideal creatinine according to height corrected on age & -0.866 & 0.000 & 7 \\
\hline Cockroft & Renal creatinine clearance/min & 0.559 & 0.01 & 3 \\
\hline Cockroft & Excreted creatinine/min according to Cockroft volume/min & 0.801 & 0.000 & 7 \\
\hline Cockroft & Voume of urine/100 & -0.459 & 0.048 & 3 \\
\hline Cockroft & Total creatinine clearance week & 0.594 & 0.006 & 5 \\
\hline weight & Ideal excreted creatinine per weight & 0.946 & 0.000 & 7 \\
\hline Normalized dialysis clearance liters week & Total excreted creatinine/day & 0.54 & 0.014 & 3 \\
\hline Normalized dialysis clearance liters week & Total excreted creatinine/BMl & 0.488 & 0.029 & 3 \\
\hline Normalized dialysis clearance liters week & Total excreted creatinine by dialysis & 0.705 & 0.001 & 5 \\
\hline Normalized renal clearance liters week & Normalized total clearance week & 0.613 & 0.004 & 5 \\
\hline Normalized renal clearance liters week & Supplementary clearance & 0.574 & 0,008 & 5 \\
\hline Normalized renal clearance liters week & Total excreted creatinine by dialysis & -0.713 & 0.000 & 7 \\
\hline Normalized renal clearance liters week & Total excreted creatinine/BMI & -0.713 & 0.000 & 7 \\
\hline Total clearance week & Total excreted creatinine by dialysis & 0,693 & 0,001 & 7 \\
\hline Volume of urine/100 & Total clearance week & 0,443 & 0.05 & 3 \\
\hline Volume of urine/100 & Normalized renal clearance liters week & 0,777 & 0.000 & 7 \\
\hline Volume of urine/100 & Total excreted creatinine by urine & 0.472 & 0.041 & 3 \\
\hline Volume of urine/100 & weight & 0.488 & 0.034 & 3 \\
\hline \multirow[t]{4}{*}{ Supplementary clearance } & Total creatinine clearance week & 0.605 & 0.006 & 5 \\
\hline & mean & 0.3 & 0.013 & 5 \\
\hline & SD & 0.59 & 0.017 & 1.72 \\
\hline & Coefficient of variation & 1.97 & 1.31 & 0.344 \\
\hline
\end{tabular}


In the four tables, the degree of significance of the correlations is based on the $p$ values. The numerical $p$ values were calculated by $\mathrm{T}$ tests to statistically compare the significance of the correlations. It was assumed to use mathematical differences to compare the significance of the correlations. A score was assigned to each $\mathrm{p}$ value according to an arbitrary scale, as follows: $\mathrm{p}$ value $=0.000$, score $=7 ; \mathrm{p}$ value less than 0.009 and greater than 0.000 , score $=5 ; \mathrm{p}$ value less than 0.05 and greater than 0.01 , score $=3$. The $p$ scores were compared according to gender, considering males versus males, males versus females, and females versus females. The results of the comparisons of the $\mathrm{p}$ scores and the values of the correlations were as follows : 1) males (Table IV) versus males (Table V), comparison of the $p$ scores: $\mathrm{T}$ value $=-1.51, \mathrm{p}=0.141$, degrees of freedom $=37$; 2) males (Table V) versus females (Table VII), comparison of the p scores: $-2.3,37, p=0.0,023$, degrees of freedom $=37$; 3 ) comparison of the correlations, males (Table IV) versus females $($ Table VI), $\mathrm{T}$ value $=-1.16, \mathrm{p}=0.254$, degrees of freedom $=36$; 4) comparison of the correlations, males $($ Table V) versus females (Table VII), $\mathrm{T}$ value $=1.66, \mathrm{p}=$ 0.107 , degrees of freedom $=30 ; 5$ ) males $($ Table IV) versus females (Table VII), comparison of the scores: T value -2.37 , $\mathrm{p}=0.023$, degrees of freedom $=37 ; 6)$ males (Table IV) versus males (Table $\mathrm{V}$ ), comparison of the correlations: $\mathrm{T}$ value $=-2.90, p=0.007$, degrees of freedom $=32 ; 7$ ) females (Table VI) versus females (Table VII), comparison of the scores: $\mathrm{T}$ value $=0.42, \mathrm{p}=0.679$, degrees of freedom $=35$.

The $\mathrm{p}$ scores significantly differed between males (Table V) versus females (Table VII) and males (Table IV) versus males (Table V). The correlations significantly differed only between males (Table IV versus Table V). The females data reported in Table VI versus those in Table VII did not significantly differ for $\mathrm{p}$ scores or for correlation degrees. The comparisons of the male data indicated two differences out of eight comparisons (25\%). The most important result is that significant differences resulted between all the variables on the basis of the Pearson correlations.

A third series of comparisons of males versus females was performed for body water, as the difference in total body water by gender and as the differences in intracellular water and extracellular water by gender. Total body water can be measured by highly precise methods or may be estimated. In this case, total body water was estimated by the formula by Watson et al. [1], while extracellular and intracellular water were extracted from the database. The extracellular water as $\%$ of Watson's total body water and the intracellular water as $\%$ of Watson's total body water were calculated. The ratio of extracellular water/intracellular water adjusted by age was obtained using two formulae according to the gender. These formulae are reported in a paper by Japanese researchers [2]: $0.5857+7.4334 \times 106 \times$ (age) 2 ; for males and $0.6062+5.5775$ $\mathrm{x} 106 \mathrm{x}$ age 2 for females. Although the formulae were developed based on a very different population, their application in the subjects of this study yielded suitable results. The data describing the different forms of body water and the ratio of extracellular water/intracellular water are reported in Table VIII; comparisons according to gender are shown in Table IX.

Table VIII and Table IX show the means and the standard deviations of the total body water calculated according to Watson and other variables pertaining to the intracellular and extracellular water. A statistical comparison of the differences between the body water variables according to gender is shown in Table IX. All the comparisons attained very significant differences. Males had larger values for all variables, with the only exception being the extracellular water/intracellular water ratio, which was greater for females. A fourth series of comparisons was performed for intracellular and extracellular water content normalized by height, weight and BMI (Table XI).

The results in Table $X$ are confirmed by the results in Table XI. The results in Table $\mathrm{X}$ differ because of the numerical definition of the differences between males and females. The last column shows the percent difference between the means. The extracellular water normalized by weight shows the lowest difference, due to its narrow range in males and females. The ranges are calculated based on the mean and the standard deviation, and for the result of extracellular water/weight, the ranges of the results were as follows: males, mean plus SDx2 =0.379, mean minus SDx2 = 0.287; females, mean plus SDx2 $=0.356$, mean minus $\mathrm{SDx} 2=$ 0.252 . The percent difference between the mean plus $2 \mathrm{SD}$ and the mean minus 2SD was $24.27 \%$ for males and $41.27 \%$ for females. The greatest percent difference was found for intracellular water/BMI: males, mean plus SDx2 $=0.865$, mean minus $\mathrm{SDx} 2=0.429$; females, mean plus $\mathrm{SDx} 2=$ 0.573 , mean minus SDx $2=0.357$. The percent difference between the mean plus 2SD and the mean minus 2SD was $50.4 \%$ for males and $37.7 \%$ for females. The sizes of the differences were fundamentally based on the magnitude of the ranges of the normalizing variables; therefore, it is advised to normalize the data by variables with low variance. The variance may be calculated by statistical software or using the formula $\mathrm{s} 2=\Sigma(\mathrm{x}-\mathrm{M}) 2 / \mathrm{N}-1$, defined as the variance of a variable $=($ sum of the differences between each item of the variable and the mean of the variable)2/the number of items in the variable -1 . The same goal can be more easily attained by using the ratio : standard deviation/the mean, i.e., the coefficient of variation, which is easy to calculate., This value may be used as a substitute of the variance because the variance is a measure of the variability of a variable, that is, it can be evaluated by the coefficient of variation. The coefficients of variation of height, weight, and BMI in this case were 0.0519 (quite low), 0.155 (high), and 0.172 (high), respectively, for males; and $0.0503,0.193$, and 0.171 , respectively, for females. Thus, height as an indexing variable induced the lowest modification of the indexed variables, as shown in Table XII. 
World Journal of Research and Review (WJRR)

ISSN:2455-3956, Volume-7, Issue-1, July 2018 Pages 28-35

\begin{tabular}{|l|c|c|c|}
\hline \multicolumn{4}{|c|}{ Table VII- Males - data concerning body water } \\
\hline Statistics & $\begin{array}{c}\text { extracellular } \\
\text { water/intracellular water } \\
\text { ratio }\end{array}$ & $\begin{array}{c}\text { Watson's total body } \\
\text { water }\end{array}$ & extracellular water \\
\hline Mean & 0.608 & 41.77 & 25.38 \\
\hline SD & 0.016 & 4.51 & 2.65 \\
\hline Coeff. Var. & 0.0175 & 0.108 & 0.104 \\
\hline & intracellular water & extracellular water \% & intracellular water \% \\
\hline Mean & 16.39 & 39.2 & 60.8 \\
\hline SD & 1.94 & 1.06 & 1.06 \\
\hline Coeff. Var. & 0.118 & 0.027 & 0.017 \\
\hline
\end{tabular}

\begin{tabular}{|l|c|c|c|}
\hline & \multicolumn{3}{|c|}{ Table VIII - Females - data concerning body water } \\
\hline & $\begin{array}{c}\text { extracellular } \\
\text { water/intracellular water } \\
\text { ratio }\end{array}$ & $\begin{array}{c}\text { Watson's total body } \\
\text { water }\end{array}$ & extracellular water \\
\hline Mean & 0.625 & 30.79 & 37.47 \\
\hline SD & 0.001 & 3.58 & 0.98 \\
\hline Coeff. Var. & 0.0157 & 0.116 & 0.026 \\
\hline & intracellular water & extracellular water $\%$ & intracellular water $\%$ \\
\hline Mean & 19.24 & 11.54 & 37.47 \\
\hline SD & 2.2 & 1.43 & 0.981 \\
\hline Coeff. Var. & 0.114 & 0.124 & 0.026 \\
\hline
\end{tabular}

Table IX - Comparison of body water for males versus females

\begin{tabular}{|l|c|c|}
\hline differences in males versus females & T value & $\mathrm{P}$ \\
\hline extracellular water/intracellular water ratio & -53 & 0.000 \\
\hline Watson's total body water & 8.31 & 0.000 \\
\hline extracellular water & 7.77 & 0.000 \\
\hline intracellular water & 8.8 & 0.000 \\
\hline $\begin{array}{l}\text { extracellular water as \% of Watson's total body } \\
\text { water }\end{array}$ & 5.22 & 0.000 \\
\hline $\begin{array}{l}\text { intracellular water as \% of Watson's total body } \\
\text { water }\end{array}$ & 70.44 & 0.000 \\
\hline
\end{tabular}

Table X - Comparison of body water locations normalized by body size for males versus females

\begin{tabular}{|c|l|c|c|c|c|c|}
\hline \multicolumn{1}{|c|}{ Variables } & Males & Females & \multicolumn{2}{c|}{ Statistics } & \multirow{2}{*}{$\begin{array}{c}\text { difference of the } \\
\text { means }\end{array}$} \\
\cline { 1 - 6 } $\mathrm{n}$. & \multicolumn{1}{|c|}{ mean \pm SD } & mean \pm SD & T value & $\mathrm{p}$ & 17.9 \\
\hline 2 & extracellular water/height & $14.67 \pm 1.35$ & $12.04 \pm 1.11$ & 6.68 & 0.000 & 8.64 \\
\hline 3 & extracellular water/weight & $0.333 \pm 0.023$ & $0.304 \pm 0.026$ & 3.68 & 0.001 & 22.64 \\
\hline 4 & intracellular water/height & $1 \pm 0.138$ & $0.775 \pm 0.082$ & 31 & 0.000 & 23.53 \\
\hline 5 & intracellular water/weight & $0.215 \pm 0.214$ & $0.182 \pm 0.016$ & 35 & 0.000 & 15.02 \\
\hline 6 & intracellular water/BMI & $0.647 \pm 0.109$ & $0.465 \pm 0.054$ & 6.4 & 0.000 & 28.1 \\
\hline
\end{tabular}


A Comparison of Body Composition, Residual Biological Function and Dialytic Treatment of 20 Males and 19 Females Undergoing Chronic Peritoneal Dialysis

Table XI - Comparison of indexed and not indexed variables concerning intracellular and extracellular body water

\begin{tabular}{|c|c|c|c|c|c|c|c|}
\hline \multicolumn{8}{|c|}{ Males } \\
\hline Variable & $\begin{array}{c}\text { Not indexed } \\
\text { value }\end{array}$ & $\begin{array}{c}\text { Indexed value on } \\
\text { height }\end{array}$ & $\begin{array}{c}\text { Indexed value on } \\
\text { BMI }\end{array}$ & $\begin{array}{c}\text { T value for } \\
\text { indexing on } \\
\text { height }\end{array}$ & $\mathrm{p}$ & $\begin{array}{l}\mathrm{T} \text { value for } \\
\text { indexing on } \\
\mathrm{BMI}\end{array}$ & $\mathrm{p}$ \\
\hline intracellular water & $16.39 \pm 1.94$ & $9.44 \pm 0.92$ & $0.647 \pm 0.609$ & 14.48 & 0.000 & 34.63 & 0.000 \\
\hline extracellular water & $25.38 \pm 2.65$ & $14.67 \pm 1.35$ & $1 \pm 0.38$ & 16.1 & 0.000 & 40.73 & 0.000 \\
\hline \multicolumn{8}{|c|}{ Females } \\
\hline Variable & $\begin{array}{c}\text { Not indexed } \\
\text { value }\end{array}$ & $\begin{array}{c}\text { Indexed value on } \\
\text { height }\end{array}$ & $\begin{array}{c}\text { Indexed value on } \\
\text { BMI }\end{array}$ & $\begin{array}{c}\mathrm{T} \text { value for } \\
\text { indexing on } \\
\text { height }\end{array}$ & $\mathrm{p}$ & $\begin{array}{c}\text { T value } \\
\text { for } \\
\text { indexing } \\
\text { on BMI }\end{array}$ & $\mathrm{p}$ \\
\hline intracellular water & $19.24 \pm 2.2$ & $7.22 \pm 0.687$ & $0.465 \pm 0.054$ & 22.73 & 0.000 & 31.79 & 0.000 \\
\hline extracellular water & $37.47 \pm 0.98$ & $12.04 \pm 11$ & $0.775 \pm 0.082$ & 74.86 & 0.000 & 162.65 & 0.000 \\
\hline
\end{tabular}

\section{DISCUSSION AND CONCLUSIONS}

Intracellular water is an indirect expression of muscle mass. Therefore, males exhibited greater dry mass than females (see Table $\mathrm{X}$ for intracellular water and intracellular water as \% of Watson's total body water, Table XI for intracellular water/BMI, and Table XII for " indexed value on height"), taking into account that the normal intracellular body water should be correlated with body size. Females exhibited a significantly higher extracellular water/intracellular water ratio than males (Table IX), which indicates that females fundamentally have a more prevalent extracellular water mass with respect to intracellular water. We focus on two examples to clarify the normalization with respect to body size. For this aim, the non indexed variables are compared with the same variables indexed by height and BMI, as shown in Table XII. Table XII shows the highest body water content in females and the relevant modifications of the actual water values due to indexation, particularly with indexation by BMI. It can be concluded that the differences between the actual body water content and the normalized body water content are strongly dependent on the indexing variable, specifically their variances, as shown above. Therefore, careful consideration should be taken regarding the calculation of body water content. The data of the different forms of body water, on which these analyses are based, were likely estimated by means of BIA (body impedance analysis), a technique that measures the resistance and reactance of body tissues to the passage of electricity flow [3]. The technical and mathematical bases of the method are described in depth by Khalil and Al. [4]. Body water content is widely measured by this method because it has been verified as a suitable method. However, its consistency with actual body water content should be prudently evaluated, particularly in cases of estimating water content that is very different from normal values, as described here.

\section{REFERENCES}

[1] P. E. Watson, D. Watson,, and Richard D. Total body water volumes for adult males and females estimated from simple anthropometric measurements. Am. J Clin. Nutr. 33: 1980. pp. 27-39.

[2] Oashi Y, Joki N., Yamazaki K., Kawamura T., Tai R., Oguchi H, Yuasa R, Sakai K. Changs in the fluid volume balance between intraand extracellular water in a sample of Japanese adults aged 15-88 yr old. : a cross sectional study. Am J Physiol Renal Physiol 2018, E-Pub 2017, pp 614-622

[3] Parenti M, Di Bartolo P, Babini AC, Sorrenti G, Saretta B, Cecchetto ME, Luchi A, Gatto MR, Melchionda N. Comparison of three methods for the rapid determination of body composition. Minerva Endocrinol. $1990 ; 15(3)$ : pp 207-14.

[4] Khalil SF, Mohktar MS, and Ibrahim F. The theory and the fundamentals of bioimpedance analysis in clinical status monitoring and diagnosis of diseases. Sensors, 2014,14: pp 10895 - 10928 